Natural Hazards and Earth System Sciences (2003) 3: 3-16

(C) European Geosciences Union 2003

Natural Hazards
and Earth
System Sciences

\title{
Combining historical and geological data for the assessment of the landslide hazard: a case study from Campania, Italy
}

\author{
D. Calcaterra ${ }^{1}$, M. Parise ${ }^{2}$, and B. Palma ${ }^{3}$ \\ ${ }^{1}$ Department of Geotechnical Engineering, Section of Applied Geology, Federico II University of Naples, Italy \\ ${ }^{2}$ National Research Council - CERIST, Bari, Italy \\ ${ }^{3}$ Vico Equense, Naples, Italy
}

Received: 27 November 2001 - Accepted: 8 January 2002

\begin{abstract}
Past slope instabilities at Quindici (one of the five towns of Campania that was hit by catastrophic landslides on 5 May 1998) and in the Lauro Valley are investigated to improve the understanding of the landslide history in the area, as a mandatory step for the evaluation of the landslide hazard. The research was performed by combining information on past slope instabilities from both historical and geological data. From numerous historical sources an archive consisting of 45 landsliding and flooding events for the period 1632-1998 was compiled. Landslide activity was also investigated by means of interpretation of multi-year sets of aerial photos, production of Landslide Activity Maps, and excavation of trenches on the alluvial fans at the mountain foothills. Detailed stratigraphic analysis of the sections exposed in the trenches identified landslide events as the main geomorphic process responsible for building up the fans in the study area. Integration of historical and geological approaches provides significant insight into past and recent instability at Quindici. This is particularly valuable in view of the limitations of individual sources of information. Application of such an approach offers potential for improved hazard assessment and risk mitigation.
\end{abstract}

\section{Introduction}

Slope movements are responsible worldwide for significant socioeconomic losses. Landslide costs are often underestimated, since the related damages are erroneously attributed to the triggering process, such as earthquakes and typhoons (Schuster, 1996). Given the ongoing pressure of increasing populations and expansion of urban areas into unstable hillslopes, the cost to society of landslides will increase in years to come.

Between 1945 and 1990 landslides and floods were responsible for 3488 of the total 7688 fatalities due to natu-

Correspondence to: D. Calcaterra

(domenico.calcaterra@unina.it) ral hazards in Italy (Catenacci, 1992), and cost the national economy some 17000 million Euro, corresponding to about 15 billion US\$ (an average cost of c. \$33 million). The human and economic costs of landslides increased dramatically in recent years.

This paper combines historical and geological approaches to reconstruct the past landslide and flood history of an area of Campania, southern Italy. The town of Quindici, and surrounding areas of the Lauro Valley (Fig. 1), are the focus for this study. Despite the long history of landsliding and flooding events in this area, two recent catastrophic events (on January 1997 and May 1998) resulted in serious damage (estimated at more than $\$ 480$ million) and significant casualties. The paper provides a detailed description of landsliding history with the aim of improving the assessment of the landslide hazard and of contributing to the mitigation of the related risk.

\section{Description of the 1998 landsliding event}

The slopes of the limestone massif of Mount Pizzo d'Alvano, above the town of Quindici, are mantled with variable thickness (generally not greater than $3-5 \mathrm{~m}$ on the slopes) of pyroclastics and epiclastics. On 5 May 1998, after $122 \mathrm{~mm}$ of rainfall, these slopes were affected by some hundreds of slope failures (Del Prete et al., 1998; Calcaterra et al., 1999). These started as soil slides in the shallow pyroclastic cover and rapidly turned to debris flows, moving downslope following the major drainage channels (Fig. 1).

During this event, local morphology, and particularly the high gradient of the valleys dissecting the mountain, favoured high mobility of the landslide debris, which reached estimated velocities of $15-20 \mathrm{~m} / \mathrm{s}$ (Calcaterra et al., 2000). Four towns located at the immediate mountain foothills were severely hit by the landslides. There were 159 fatalities (11 at Quindici on the northern mountain slopes, the remaining in the towns at the southern and eastern sides of Pizzo d'Alvano) and about 100 million dollars in property losses. 


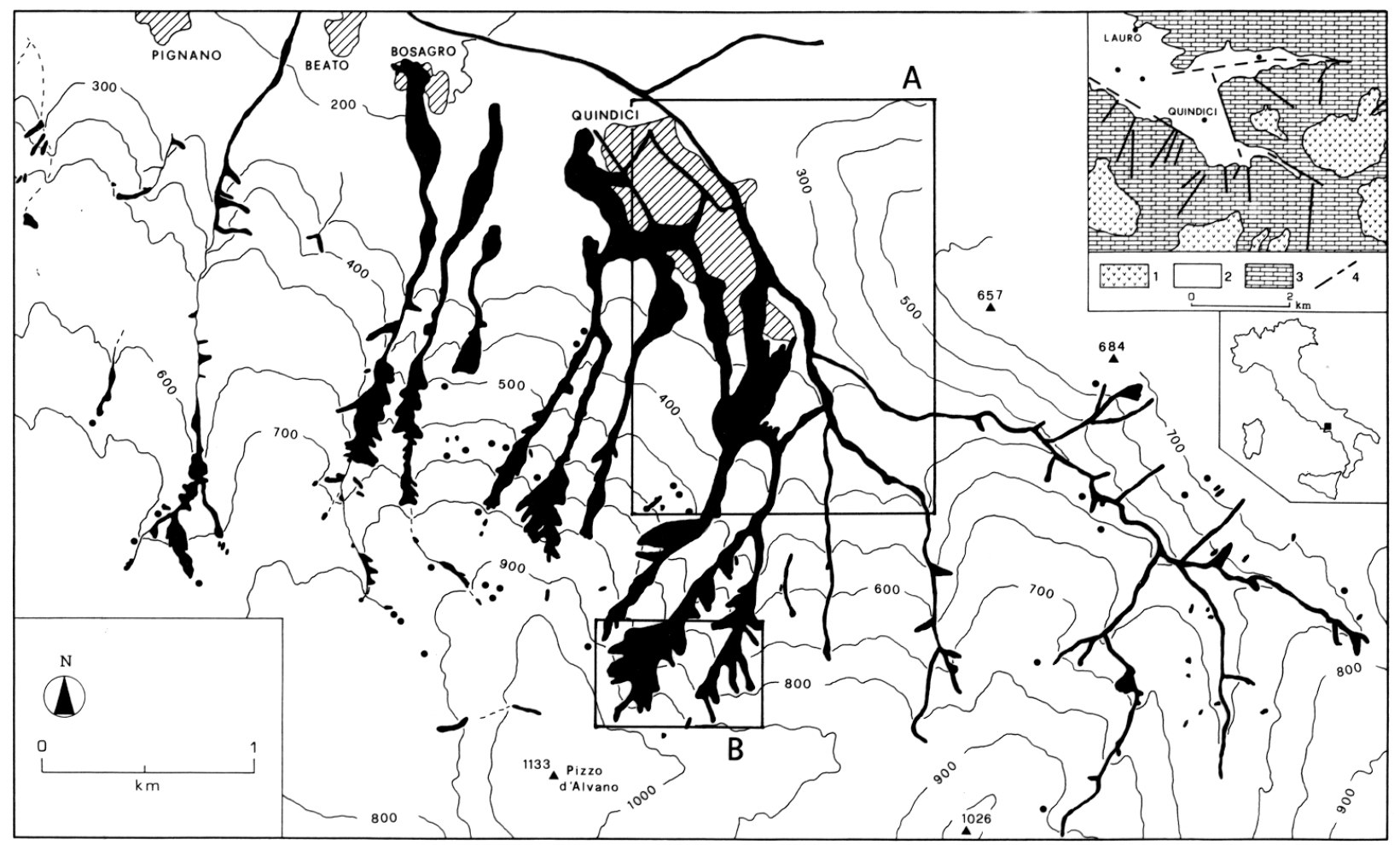

Fig. 1. Distribution of the 5 May 1998 landslides in the Quindici area. Small dots indicate the location of unmappable slope failures. Rectangle A refers to Fig. 5, rectangle B to Fig. 9. Contour interval $100 \mathrm{~m}$. In the inset, geological sketch of study area. Legend: (1) Pyroclastics (Holocene - Late Quaternary); (2) Alluvial and fan deposits (Holocene - Quaternary); (3) Carbonate bedrock (Tertiary Mesozoic), mantled by pyroclastics and epiclastics; (4) Fault (presumed when dashed).

Pyroclastic materials in the area are derived from explosive eruptions related to the Late Quaternary to historical activity of Somma-Vesuvius and the Phlegrean Fields. They comprise a complex sequence of layered tephra products interbedded with paleosoils (Scandone et al., 1991; Rolandi et al., 1993b, 1993c). The abundance of the pyroclastics in the study area is due to the prevailing W-E and SW-NE winds, which controlled diffuse deposition of airfall pyroclastic deposits (Barberi et al., 1990).

\section{Landslide and flood history at Quindici and in the Lauro Valley}

Two contrasting but interrelated approaches were adopted to study past events of flood and/or landslide in the area. The historical approach involved research, collection, and validation of any information about the occurrence of landslides and floods reported in various types of historical sources. The geological approach consisted of analysis of any evidence left by past events within the morphological and stratigraphic record of the study area.

It proved challenging to differentiate between flood and landslides impacts from historical information, despite their very clear and important differences in terms of geological processes. This problem arose from the unprecise terms used for describing the events in most of the historical sources, and from the difficulty for non-specialists to distinguish the two event typologies. This discrimination is a particular problem due to the type of slope movements involved (rapid to very rapid earth- to debris-flows, deriving generally from shallow soil slips), their close relationships with rainfall as a triggering factor, and their similar effects on the anthropogenic environment. Thus, to minimise errors of interpretation from the original sources, each and every event was reported as it appeared in the original text without interpreting them, except when their attribution was univocal. Main events identified in this study are summarized in Fig. 2, while all of them are listed in Table 1.

\subsection{Historical data}

The first stage of the historical research consisted of the analysis of existing Italian catalogues of landslides and floods: these were the inventories of landslides made in 1957 and 1963 by the Ministry for Public Works (Ministero dei Lavori Pubblici, 1965), the archive of the AVI Project (the acronym is for Areas Vulnerable to landslides and floods in Italy), available at the web site www.gndci.pg.cnr.it, and the catalogues collected in the first and in the last decades of the 20th century by, respectively, the geographer Roberto Almagià (1910), and the geologist Vincenzo Catenacci (1992). All of these catalogues covered the whole of Italy, and the level of detail of records is thus generally not very high. 
Table 1. List of flood and landslide events in the territory of Quindici and the Lauro Valley

\begin{tabular}{|c|c|c|c|}
\hline No. & Date & Event and location & Source \\
\hline 1 & 1632 & Flood (Quindici) & Scandone, 1983 \\
\hline 2 & 25 October 1640 & Flood (Quindici): 40 victims, 1 missing & Amelia, 1990, 1996 \\
\hline 3 & 1655 & Flood (Quindici): silting up of Church S. Liberatore & Amelia, 1990 \\
\hline 4 & October 1660 & Flood (Lauro): damage to Church of Pietá & Scandone, 1983 \\
\hline 5 & 1745 & Landslide (Quindici): 1 victim & Amelia, 1990 \\
\hline 6 & 1780 & Landslide (Lauro, loc. Pretruro): some victims & Di Maio and Scala, 2000 \\
\hline 7 & 5 September 1781 & Flood (Lauro, loc. Pretruro): 2 victims & Bonavita, 1837 \\
\hline 8 & 1798 & Some landslide activity (Quindici, loc. Cognolo, Maione) & State Archive, Avellino (1) \\
\hline \multirow[t]{2}{*}{9} & 1814 & Some flood and landslide activity & \\
\hline & & (Quindici, loc. Bosagra and Beato) & State Archive, Avellino (1) \\
\hline 10 & $1819-1823$ & Repeated floods (Lauro) & State Archive, Caserta (1) \\
\hline 11 & 1821 & Flood (Lauro): 1 victim & Bonavita, 1837 \\
\hline 12 & 5-6 June 1822 & Flood (Quindici, loc. S. Michele) & State Archive, Caserta (1) \\
\hline 13 & February 1841 & Flood and landslides (Quindici, Moschiano): damage to buildings & Migale and Milone, 1998 \\
\hline 14 & Oct.-Nov. 1843 & Landslides (Quindici) & Migale and Milone, 1998 \\
\hline 15 & 1844 & Landslides (Quindici) & Migale and Milone, 1998 \\
\hline 16 & 23 November 1851 & Landslide (Quindici, loc. S. Maria della Neve) & State Archive, Avellino (1) \\
\hline 17 & 1853 & Some flood activity (Quindici, Forino) & State Archive, Avellino (1) \\
\hline 18 & 17 June 1872 & Flood (Moschiano): 1 victim & Amelia (unpubl. rep., 1998) \\
\hline 19 & October 1877 & $\begin{array}{l}\text { Flood and landslides (Quindici, loc. Beato): } \\
\text { damage to buildings and cultivated land }\end{array}$ & Migale and Milone, 1998 \\
\hline 20 & 28-29 November 1882 & Flood (Quindici, loc. S. Michele) & State Archive, Avellino (1) \\
\hline 21 & 1889 & $\begin{array}{l}\text { Some flood activity from Colafasulo Valley } \\
\text { (Quindici, loc. Bosagra and Beato) }\end{array}$ & State Archive, Avellino (1) \\
\hline 22 & 1898 & $\begin{array}{l}\text { Some flood activity from Colafasulo Valley } \\
\text { (Quindici, loc. Bosagra and Beato) }\end{array}$ & State Archive, Avellino (1) \\
\hline 23 & 1922 & Flood (Moschiano): town inundated & Quindici Municipality (1) \\
\hline 24 & July 1924 & Flood (Moschiano) & Di Maio and Scala, 2000 \\
\hline 25 & 1926 & Some flood activity (Quindici) & Quindici Municipality (1) \\
\hline 26 & 23 November 1947 & Flood (Quindici, loc. Molini) & Quindici Municipality (1) \\
\hline 27 & December 1947 & Flood and landslides (Quindici, several localities) & Quindici Municipality (1) \\
\hline 28 & February 1948 & Flood (Quindici) & Quindici Municipality (1) \\
\hline 29 & 17 May 1948 & Flood (Moschiano, Quindici) & Quindici Municipality (1) \\
\hline 30 & 1-2 October 1949 & $\begin{array}{l}\text { Flood (Lauro, loc. Pretruro, Ima and Fontenovella; Quindici, } \\
\text { loc. Beato and Bosagro): } 1 \text { victim }\end{array}$ & Quindici Municipality (1) \\
\hline 31 & 1957 & Landslide (Quindici, loc. Giritielli) & Amelia (pers. comm.) \\
\hline 32 & 10-12 July 1959 & Flood (Quindici, loc. S. Michele, S. Teodoro and Molini) & Quindici Municipality (1) \\
\hline 33 & 1963 & Landslide (Quindici, loc. la Montagna) & Ministero Lavori Pubblici, 1965 \\
\hline 34 & 1976 & Landslide activity (Quindici) & Migale and Milone, 1998 \\
\hline 35 & 1977 & Landslides activity from Pietre della Valle Valley (Quindici) & Migale and Milone, 1998 \\
\hline 36 & 4 April 1978 & Landslides (Quindici, loc. Connola, Casapiana) & Migale and Milone, 1998 \\
\hline 37 & 8-10 April 1978 & Landslides (Quindici and neighbouring towns) & Langella (pers. comm.) \\
\hline 38 & 1979 & Landslides activity from Pietre della Valle Valley (Quindici) & Migale and Milone, 1998 \\
\hline 39 & 1980 & Landslides activity from Pietre della Valle Valley (Quindici) & Migale and Milone, 1998 \\
\hline 40 & 27 August 1990 & Flood and landslides (Moschiano, Quindici, Lauro) & Moschiano Municipality (2) \\
\hline 41 & 4 May 1993 & Landslides (Moschiano) & A.V.I. Project (3) \\
\hline 42 & 26 December 1993 & Flood (Quindici) & A.V.I. Project (3) \\
\hline 43 & 10 January 1997 & Landslides (Quindici, Bocca dell'Acqua and other localities) & Quindici Municipality (2) \\
\hline 44 & 13 November 1997 & Flood (Lauro, loc. S. Maria; Moschiano, Quindici): 1 victim & Quindici Municipality (2) \\
\hline 45 & 5 May 1998 & Landslides (Quindici, Lauro): 11 victims & \\
\hline
\end{tabular}

(1) in Aversano and Ruggiero (2000); (2) unpublished report; (3) www.gndci.cnr.pg.it

Nevertheless, in some cases, they can provide much interesting information (see, for example, the significant amount of high-quality information extracted from Almagià's work by
Calcaterra and Parise, 2001, for a sample area in Calabria). Regarding Quindici and neighbouring territories, no information was reported by either Almagià or Catenacci. 


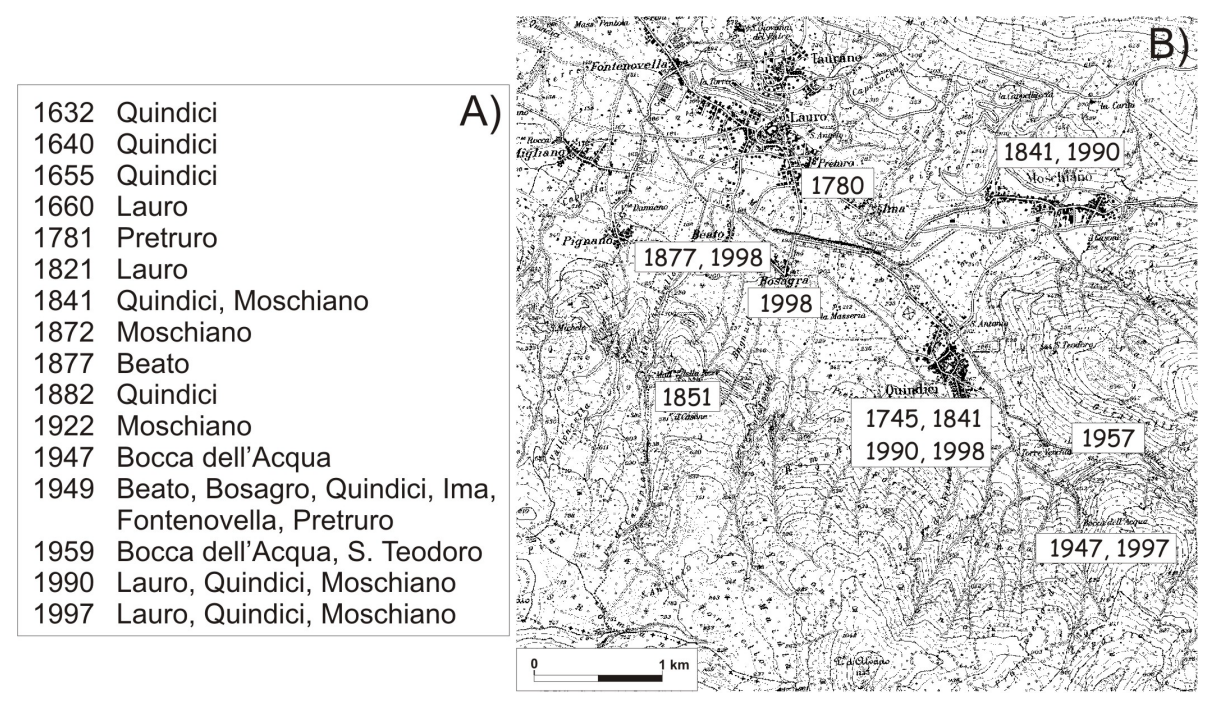

Fig. 2. Location of the main flood (a) and landsliding events (b) identified during this study.
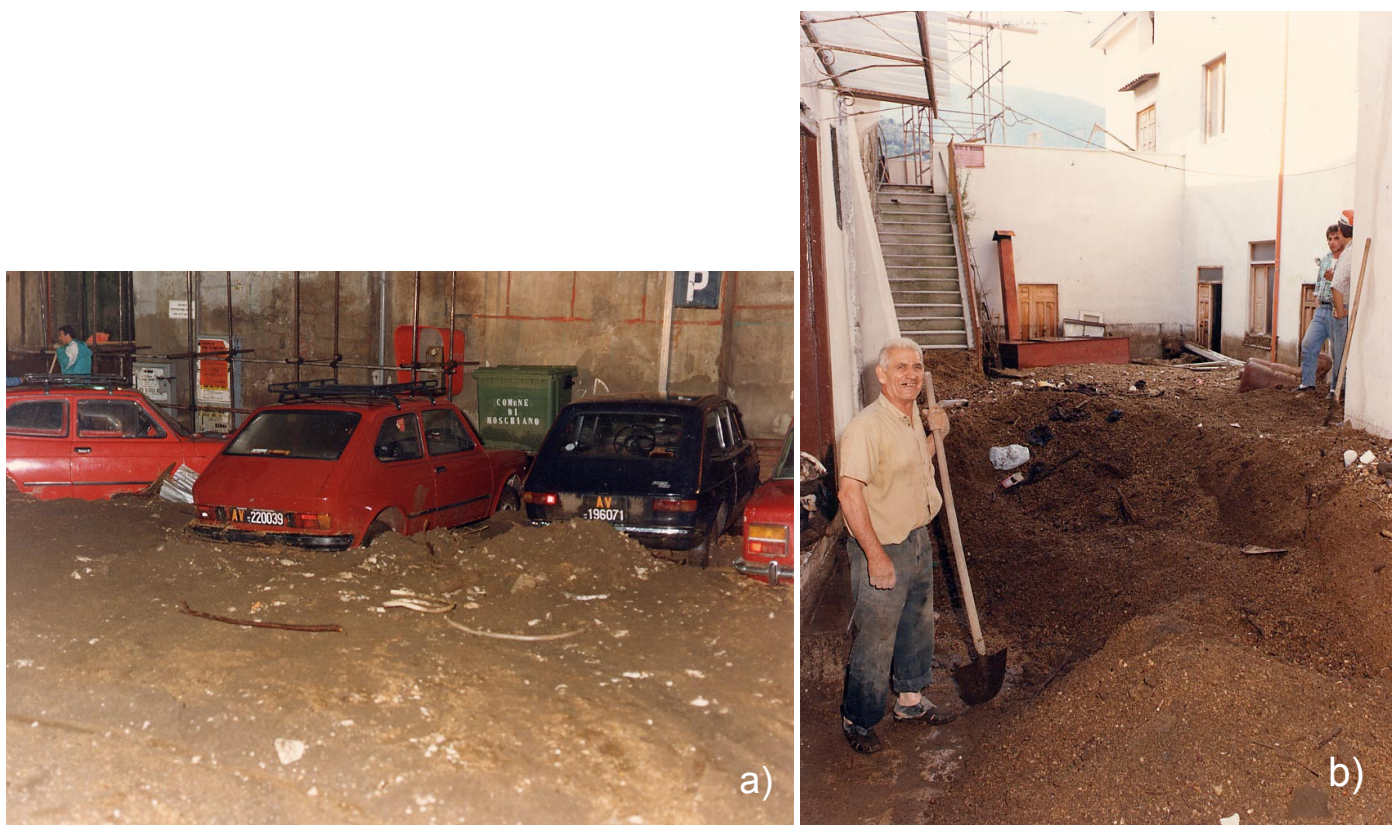

Fig. 3. Effects of the 27 August 1990 flood at Moschiano (photos by courtesy of Moschiano Municipality). On that occasion $30.8 \mathrm{~mm}$ of rainfall occurred in about one hour, and several roads (a) and some private houses (b) were blocked by some decimetres of muddy debris.

The AVI Project is the most complete and updated inventory of information on areas historically affected by landslides and floods in Italy. The project was commissioned in 1991 by the Minister of Civil Protection to the National Research Council of Italy, and currently includes more than 9300 landslides and floods in the Italian territory (Guzzetti et al., 1994). As far as Quindici and neighbouring towns are concerned, three events were initially extracted from the AVI archives (which cover the time span from 1918 to 1990), all coming from "Il Mattino", a national newspaper printed in Naples. In all cases, no locality was mentioned and in one of them (excluded from Table 1) even the date was missing.
The same uncertainty affects the only event reported in the inventory performed by the Italian Ministry for Public Works (Ministero Lavori Pubblici, 1965). In this case, the locality affected by landslide activity in the Quindici territory is simply cited as "La Montagna", which can be translated as "the Mountain".

A further national level catalogue analyzed to find additional information on landslides at Quindici and surrounding areas was the recent new edition of the Catalogue of Strong Italian Earthquakes from 461 B.C. to 1997 (Boschi et al., 2000). This catalogue, well beyond analysing seismic events in great detail, also reports information on their environmen- 


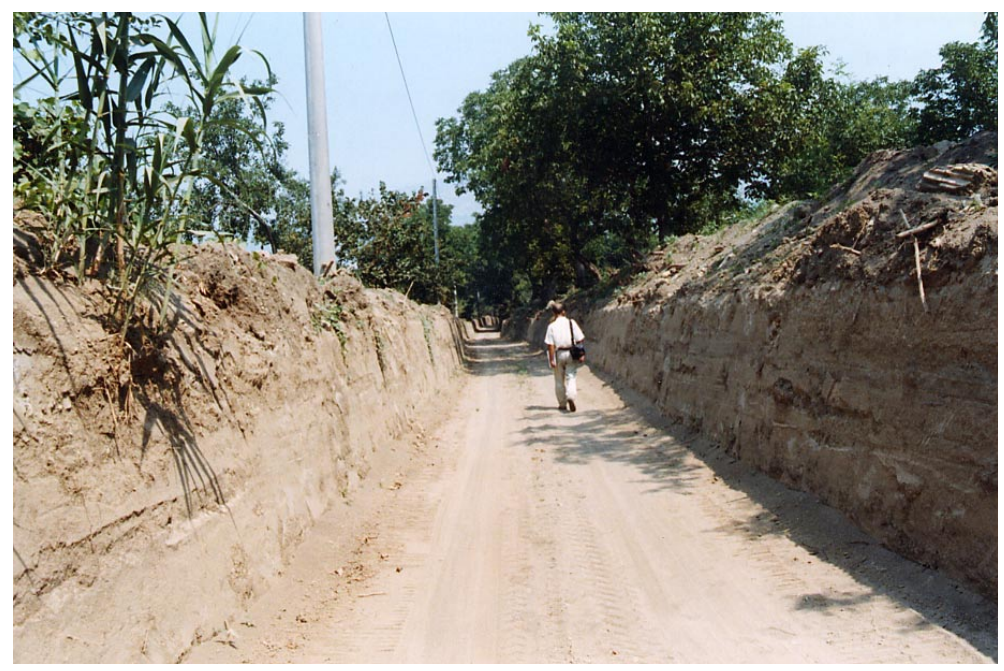

Fig. 4. One of the many channels ("Regi Lagni") built by Bourbon Kings in the 18th century to facilitate flow of water and mud from the frequent flood and landsliding events (photo taken in July 1998). The channel (some $3.5 \mathrm{~m}$ wide and $2 \mathrm{~m}$ deep) was completely filled at the time of the 5 May event, and had been used until that time by local farmers to have access to the fields by car: for this reason it was called an "alveo-strada" (channel-road). The network of channels at Quindici and in the Lauro Valley was cleared in 1998 a few days after the landslides had already hit the inhabited areas.

tal impacts. Accessing the catalogue by locality, it appears that the study area was hit by at least six strong earthquakes in the considered time span. Despite recorded effects, such as various types of slope movements, ground ruptures, and variations in water discharge from springs, not a single landslide was reported in the catalogue at Quindici or in the Lauro valley. This suggests that seismic events have not played a significant role in triggering debris flow-type movements on slopes in this area.

After this first phase of research, our study moved towards analysis of information available in books, documents and works of a more local interest. Several interviews with the local authorities were carried out, and the documents available at the Municipal Technical Offices at Quindici, Lauro and Moschiano, and at Comunità Montana "Vallo di Lauro e Baianese" (a local management agency, of intermediate rank between the central government and municipalities) were examined. Despite detailed research, again a very small amount of data with temporal reference was collected (4 events; see Table 1). However, good documentation, including several photographs (Fig. 3), was found for the three most recent events.

Publications of local interest, which focused the attention on the history of Quindici and Lauro Valley from the perspective of religious and social events were particularly revealing. The works of Amelia, the present-day parish priest of Quindici, reveal the severe and frequent menace posed by slope movements from Mt. Pizzo d'Alvano over the centuries. At Quindici several churches (many of which no longer exist) suffered severe damages from floods or landslides. For example, floor and roof levels at the church of the Immacolata have been raised more than $1.5 \mathrm{~m}$ since its construction in 1636, due to deposition of flood and/or landslide material (Amelia, 1990). The same fate befell to the church of S. Antonio Abate, which in 1625 was abandoned because it lay below ground level, and to the churches of S. Liberatore and Montevergine (Amelia, 1981, 1990). The church of S. Lucia, which was located close to Via Casamanzi (the area where most of the damage and the 11 casualties were recorded during the 5 May 1998 event), was repeatedly affected by floods and landslides, and had to be abandoned in the early 1960's. Today, only a few remnants of the original walls of the church are still visible.

A significant part of the historical research involved examining the scientific publications dealing with landslides in Quindici and surrounding areas, and, in general, those concerning debris flows and floods in the volcaniclastic materials of Campania region. At a regional scale, early pioneering studies were carried out on specific instability events in pyroclastic materials mantling carbonate slopes. A number of workers, including Lazzari (1954) and Penta et al. (1954) describe the huge flood and landslide event which struck the town of Salerno and the Amalfi coast on 26 October 1954. A total of $504 \mathrm{~mm}$ of rainfall fell in about $16 \mathrm{~h}$, causing an impressive number of soil slide - debris flows and flooding of several urban areas, resulting in some 300 fatalities.

Similarly, in the aftermath of the May 1998 catastrophic landsliding, local historians performed archival searches on past slope instabilities in various areas of the Campania region. Aliberti (1999) focuses on Siano, situated, as Quindici, in the foothills of Mt. Pizzo d'Alvano, and surrounding areas of both Salerno and Avellino provinces. This work reports repeated episodes of floods and landslides in this part of Campania since the sixteenth century. At a region scale, the earliest comprehensive analysis of past slope instabilities involving the pyroclastic cover was carried out in 1998 by Migale and Milone. They compiled the first list of floods and debris flows during the last four centuries over the whole Campanian territory. For Quindici and the Lauro Valley, nine events were mentioned, although the overall quality of the information tends to decrease for more recent events (Table 1), due to vagueness in the recording of both location and timing.

Two years later, the State Archive of Salerno published what has been to date the reference volume on past slope instabilities of Pizzo d'Alvano and neighbouring towns (Aver- 
sano and Ruggiero, 2000). This was based on a thorough investigation of several municipality and province-based state archives from which a broad database was constructed. Historical slope instabilities of the towns struck by the 5 May 1998 disaster are documented: date and localities are generally indicated, although the aforementioned uncertainty regarding the typology of events (landslide or flood) remains.

The work is of particular interest because it also includes a number of original texts and reports concerning both deforestation of mountain slopes and a lack of maintenance of natural and manmade channels. Deforestation was mentioned as early as at the end of 18th century. In 1791 the slopes in the Quindici territory were clear-cut to supply the Bourbon Royal Navy with good wood for their ships (Aversano, 2000). A further reference to deforestation dates back to 1814 , when a land surveyor observed that the villages of Beato and Bosagro (two small hamlets, administered by the Quindici Municipality; see Fig. 1 for location) had to be frequently evacuated after intense cultivation was started on the cleared slopes of Mt. Pizzo d'Alvano.

Construction of an extensive and complex network of channels, termed the Regi Lagni (Fig. 4), was started in the 16 th century under the Spanish Viceroyalty and completed in 18th century by the Bourbon Kings. It covered an extension of several hundreds of square kilometres, from the lower slopes of Mt. Pizzo d'Alvano and Mt. Somma-Vesuvius, through the Volturno River plain, to the Tyrrhenian Sea. However, the inadequacy of the Regi Lagni was underlined by the repeated floods which occurred at Quindici and in the Lauro Valley during the 19th century. Many technical reports refer to severe damages suffered by Regi Lagni, including destruction of a number of check dams (locally called "catene", i.e. chains) by floods or landslides. At that time, cleaning of the channels, which had filled with sediment to a depth of several metres, was an urgent necessity. Debris was removed with teams of buffalo, their passage (locally termed as "mena delle bufale") allowing for the finer fraction of the deposits to be re-suspended and washed away (Aversano, 2000).

\subsection{Geological evidence}

The other approach adopted in our search for past landsliding and flooding events at Quindici and in the Lauro Valley was to examine geological evidence of past slope instability. This is considered here in terms of pre-historical activity (reconstructed from geological-geomorphological evidence) and documentary evidence of historical activity.

\subsubsection{Pre-historical activity}

The most striking geomorphological features in the Quindici area are a number of fans (Figs. 5 and 6) which have built up in the upper Lauro Valley, including the site where most of the town of Quindici lies (Brancaccio et al., 1999; Calcaterra et al., 1999). Several generations of fans were initially identified from aerial photographs. Comparable fans have recently been described in nearby areas, including the Clanio and Ac- qualonga Torrents near Avella and Baiano, some five kilometres north from Quindici (Di Vito et al., 1998).

Geological studies of the fan deposits at the mouth of the main channels dissecting Mt. Pizzo D'Alvano was undertaken to assess the relative importance of processes (waterlaid transport and debris flows) contributing to fan build-up. A number of stratigraphic and sedimentologic features were looked for and investigated in the field, which are typical of debris-flow deposits (Larsen and Steel, 1978; Costa and Jarrett, 1981; Blair and Mc Pherson, 1994). These include: (1) very poorly to extremely poorly sorted deposits, lacking sedimentary structures; (2) matrix-supported deposits; (3) a wide range of particle size, with prevalence of angular clasts; (4) random orientation of larger clasts in the deposit; (5) sharp abrupt contacts; (6) buried U-shaped channels. The aforementioned features were investigated at all available exposures on the fans, as well as in trenches excavated in the main fan at Quindici, at the mouth of the S. Francesco Valley.

Trenching permits inspection of a continuous geologic section, and direct observation of geologic deposits related to natural hazards. As noted by Hatheway and Leighton (1979), many geologic problems that would otherwise remain undetected can be recognized and interpreted from trench exposures, and geologic hazards can thus be better prevented. Given its scientific value and relatively low cost, the use of trenching as an exploratory method for the evaluation of the materials building up the fans was adopted. Several trenches were, therefore, judiciously located, excavated and logged on the main fan of the Quindici area. In addition to detailed collection of data, in both graphic and note form, documentary photographs and videotapes were taken to guarantee permanent record of the exposures.

Furthermore, many stratigraphic sections were investigated in the foothill fans. These are typified by a $10.7 \mathrm{~m}$-high section at the mouth of the Pietra della Valle Valley (Fig. 7), which was cleared out from the vegetational cover due to the passage of the debris flow material in 1998. This permitted identification of several units within the stratigraphic record (Fig. 7a). The entire sequence showed features of both alluvial and debris-flow origins, but with a significant presence of deposits related to large debris flows (such as unit B, Fig. 7b).

Analysis of the fan deposits from available exposures and purpose-made trenches showed that the fans were essentially formed by reworking of volcaniclastic materials, originating from the many explosive eruptions in the last $37 \mathrm{ka}$ at Somma-Vesuvius and the Phlegrean Fields. In greater detail, the fan sequences consist of several superimposed sedimentary bodies, whose origin can be distinguished from sedimentologic and stratigraphic features. The most common types of deposits in the fans are hyperconcentrated flows and flood deposits, as observed in other studies of nearby areas (Di Vito et al., 1998). All of the examined sites also showed debris flow deposits, testifying to the importance of these processes in the removal of airfall pyroclastics from the Mt. Pizzo d'Alvano slopes. Thus, the fans at the foothills of Mt. Pizzo d'Alvano are of the mixed origin (Jackson et al., 1987), 

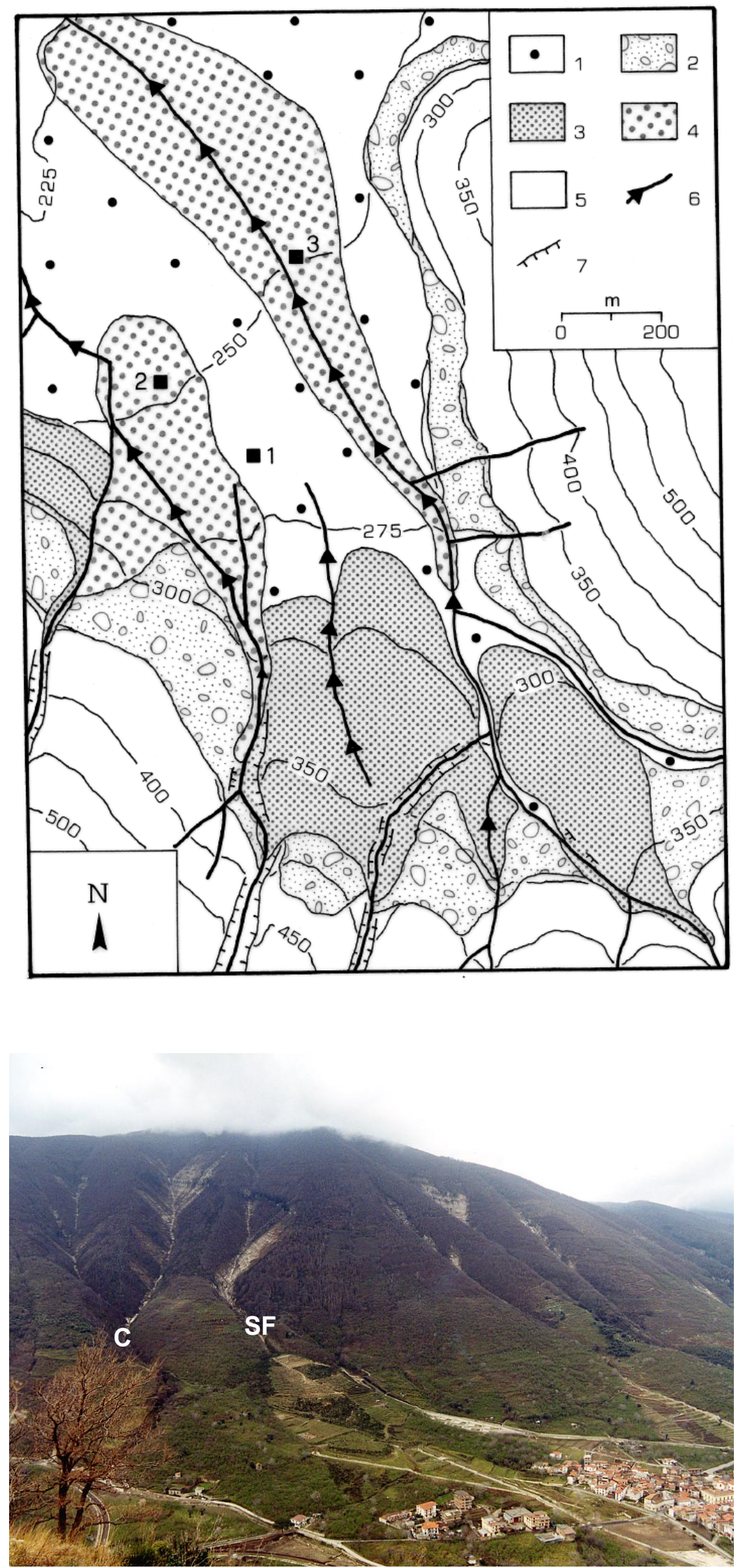

Fig. 5. Geomorphological map of the area south of Quindici. Explanation: (1) Alluvial deposits; (2) Talus deposits; (3) Post-glacial alluvial fan deposits; (4) Würm alluvial fan deposits; (5) Carbonate bedrock, mantled by pyroclastics and epiclastics; (6) Hydrographic network (arrows indicate the channels with evidence of anthropogenic alteration, such as filling, narrowing of the section, usage as road or cultivated land); (7) Valley walls higher than $3 \mathrm{~m}$. To facilitate the reader in locating the town, numbered squares indicate some of the main buildings in the inhabited area of Quindici: no. 1 is the Town Hall, no. 2 the school building, no. 3 the S. Antonio Church. Contour interval $50 \mathrm{~m}$ above elevation of $300 \mathrm{~m}$ a.s.l., and $25 \mathrm{~m}$ below it.

Fig. 6. Overall view of Mt. Pizzo d'Alvano upslope from Quindici (photo taken in March 2001): to the left of the photo, the landslides in the two gullies of Connola Valley (C) and in S. Francesco Valley (SF) are clearly visible. Note the smooth morphology of the fans at the mouth of the valleys, and especially that at the mouth of S. Francesco Valley. Some of the recently made remedial works are visible in the photo. 

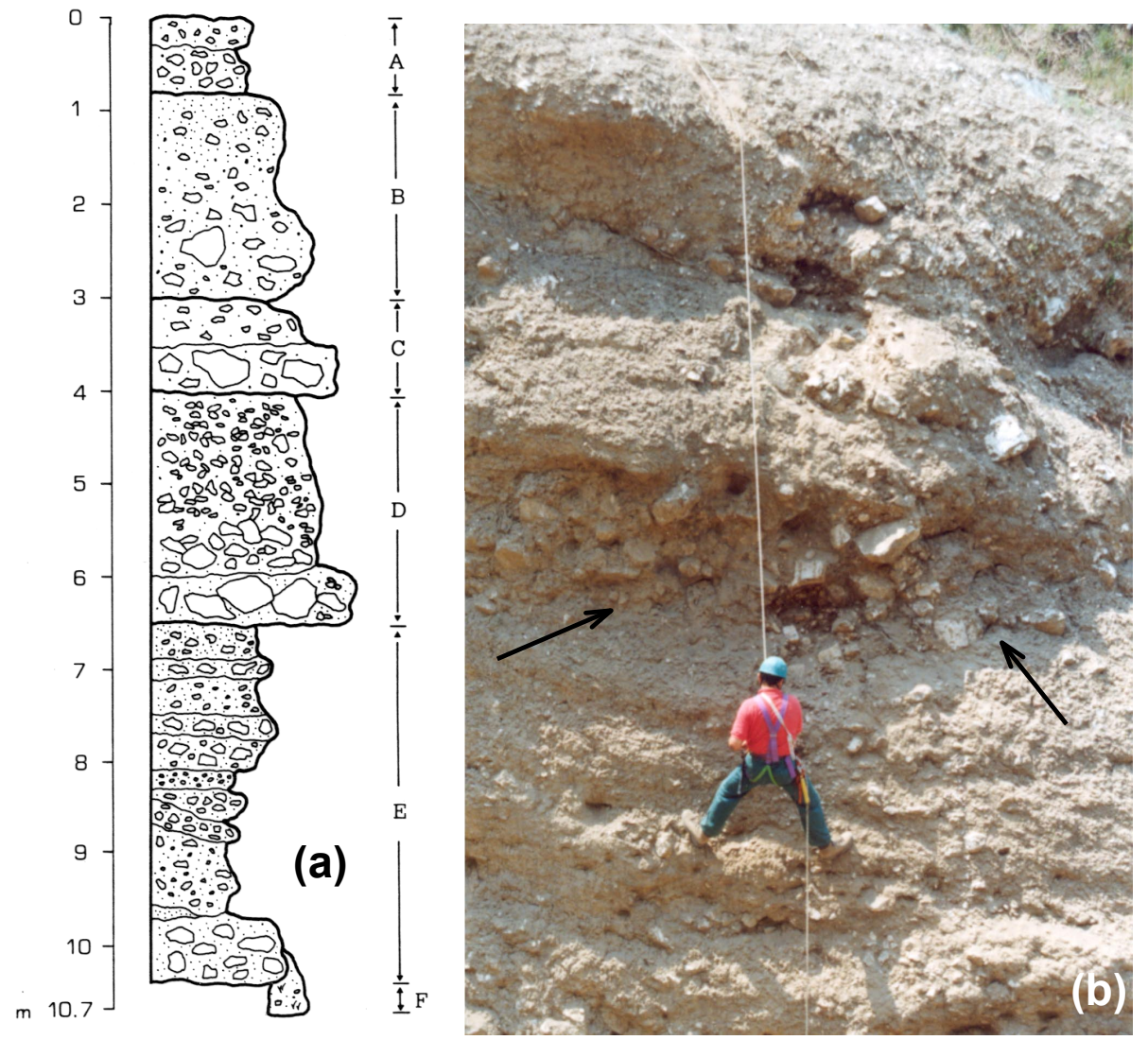

Fig. 7. (a) Stratigraphy of the $10.7 \mathrm{~m}$ high section of fan deposits at Pietra della Valle. Explanation of identified stratigraphic units: (A) Water-laid deposits; (B) Likely debris-flow deposits; (C) Deposits showing mixed characteristics; (D) Water-laid deposits; (E) Prevailing debris-flow deposits, with presence of water-laid deposits; (F) Original cover of the valleyside. (b) Photograph showing details of the upper part of the section, from unit A to about unit D; debris-flow deposits of stratigraphic unit B are pointed out by black arrows.

built through a combination of alluvial and gravity-related processes. This testifies of the importance of such phenomena in the pre-historical landsliding activity of the area.

\subsubsection{Historical activity}

The oldest landsliding and flooding events for which we found historical documentation date back to the 17th century (Table 1) and relate strictly to the volcanic activity of Mt. Vesuvius. Further significant evidence of the past slope movements in the Quindici area is the limited presence on the slopes of deposits related to the 1631 Vesuvian eruption. This eruption, as reconstructed from historical data (Rolandi et al., 1993a; Rosi et al., 1993), was characterized by emission of fall deposits and several pyroclastic flows, followed by a number of lahars, spreading over the northern and southern reaches of the area. As a result, the cone of Vesuvius was truncated more than $200 \mathrm{~m}$. Furthermore, several floods occurred for many days after the eruption in the plain to the north and northeast of the volcano (Rosi et al., 1993). Light greenish to dark green porphyritic pumice (with centimetric leucite phenocrysts) and abundant lithics represent the peculiar features of the eruptive products of this sub-plinian event. In the study area, the thickness of the fall deposits is
Table 2. Date and average scale of aerial photograph sets used in the study

\begin{tabular}{cc}
\hline Date & Scale \\
\hline 1954 & $1: 32000$ \\
$1968-1969$ & $1: 25000$ \\
1974 & $1: 17000$ \\
14 January 1997 & $1: 6800$ \\
9 May 1998 & $1: 8500$ and 1: 25000 \\
\hline
\end{tabular}

of the order of $20-40 \mathrm{~cm}$ (Rosi et al., 1993). During our surveys, the 1631 deposits were found in place only as isolated patches, with very limited lateral continuity in the middleupper reaches of the northern slopes of Mt. Pizzo d'Alvano. Combined with their diffuse presence in the fan deposits as reworked materials, this suggests that most of the 1631 airfall deposits were removed from the slopes during the first slope instability events that followed the eruption (Table 1).

Landslide activity in the last 50 years at Quindici was then assessed through the interpretation of multi-temporal aerial photograph sets, and the production of Landslide Activity 


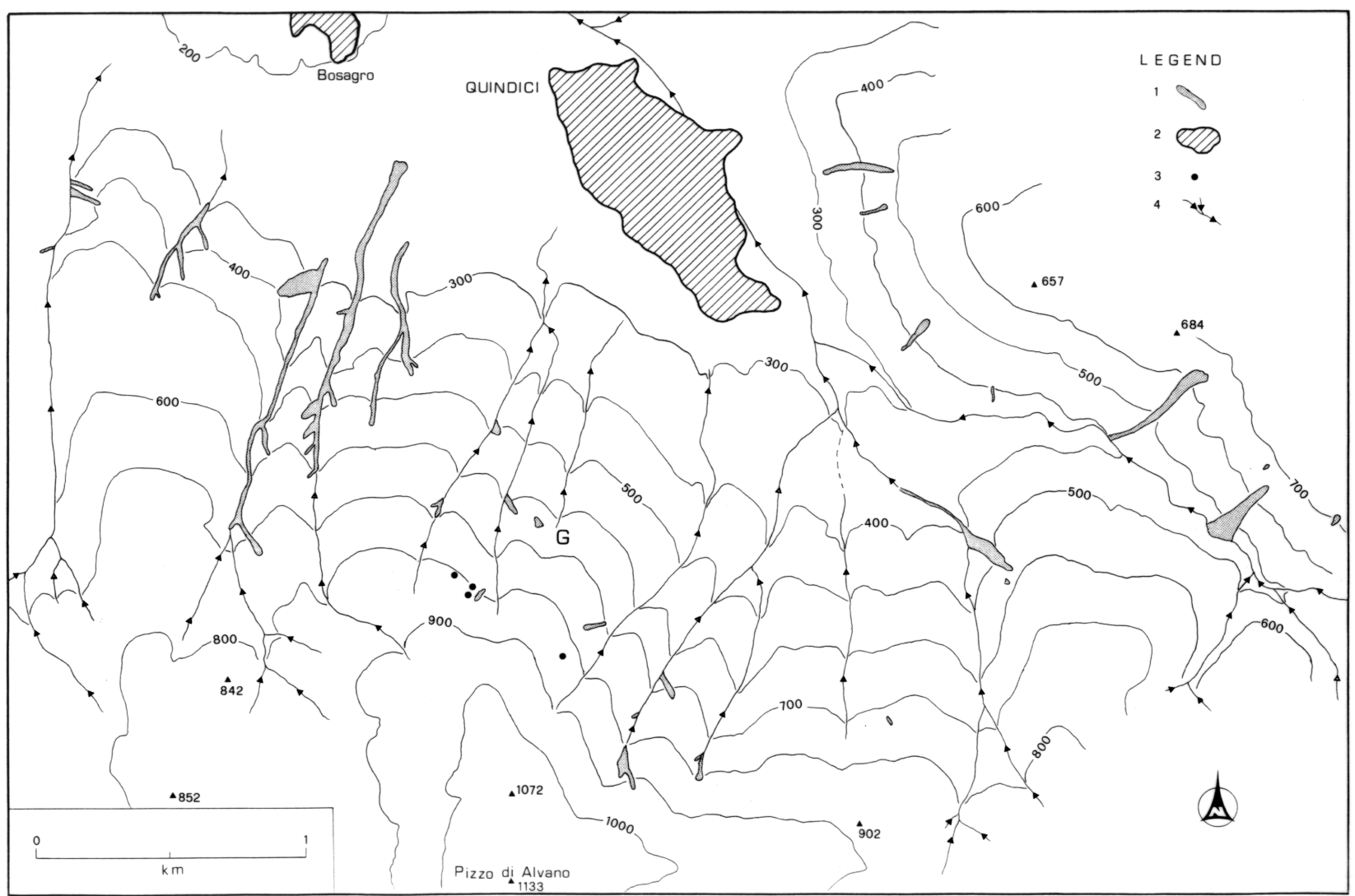

Fig. 8. Distribution of the January 1997 landslides in the Quindici area. Legend: (1) Soil slide - debris flow; (2) Inhabited area; (3) Unmappable landslide; (4) Main hydrographic network.

Maps (Soeters and van Westen, 1996; Parise and Wasowski, 1999). These maps represent a shortcut in the assessment of the hazard related to slope movements, since they focus on the effects of slope instability rather than on the causal conditions and processes. At the same time, landslide activity maps provide useful information on the overall landslide hazard in an area, allowing for the evaluation of the morphologic changes which occurred in time spans of years to tens of years, as well as temporal trends in landslide activity.

At Quindici, we used 5 sets of aerial photographs (Table 2), spanning from 1954 to 9 May 1998 (a few days after the catastrophic 5 May landsliding event). In addition, information obtained through photo interpretation was integrated and updated by field checks carried out from June 1998 to June 2001. The overall quality of aerial photos was good to very good, with the exception of the 1997 set (long shadows in the photos, and partial coverage of the mountain slopes).

However, for the most common type of slope movements in the study area (shallow failures in the volcaniclastic materials overlying carbonate bedrock), the utility of multitemporal aerial photographs is limited due to the short persistence of the forms related to landslide occurrence. Rapid coverage by soils and re-occupation by vegetation means that most landslide source areas, especially those small in size, are concealed within a few years. This implies, in turn, a greater degree of uncertainty in the identification of the land- slides and definition of their limits (Wieczorek, 1984). Nevertheless, particularly for large landslides, such as those of the 5 May 1998 event, large-scale aerial photographs are a fundamental tool which permits detailed analysis when integrated with field checks.

Landslide activity maps illustrated a general trend of increasing landslide activity in the Quindici territory from 1954 to 1998 (Figs. 1 and 8). Most of this activity was related to anthropogenic interventions on the slopes, and in particular to opening of mountain pathways. Multi-temporal analysis of air photographs showed a large increase in both number and extension of road paths, especially in the last twenty years (Fig. 9). The paths were created by cutting into the upslope side of the hill and by depositing material on the downslope side. However, in the absence of any drainage work, the paths worked to focus flow during major storms. It is clear during the 1998 event that many of the landslide source areas originated on, or in proximity to, the pathways (Fig. 9).

Comparison of terrestrial photographs was also performed for some of the slope failures on the northern slopes of Mt. Pizzo d'Alvano, for which photos shot soon after the January 1997 landsliding event were available (Fig. 10). The comparison showed that in some cases the landslides triggered during the 1998 event were enlargements of slope failures which occurred 16 months earlier. This has very im- 


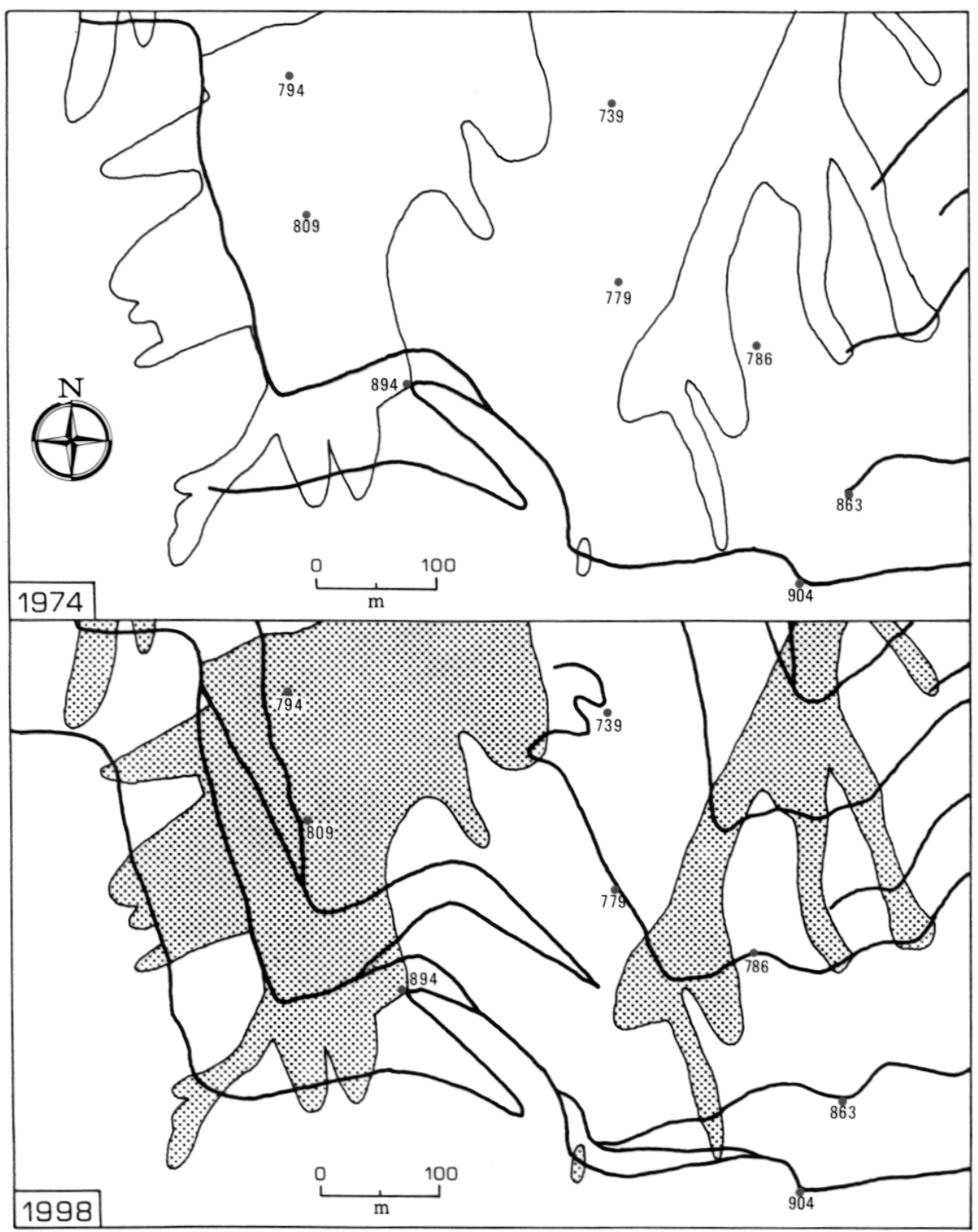

Fig. 9. Maps showing evolution of the pathways (boldlines) from 1974 to 1998 in the Connola - S. Francesco area. Note the high increase of pathways in the considered time span, and the proximity of many 1998 landslide source areas to the pathways. Moreover, it has to be mentioned that interpretation of the 1968 set of air-photos showed that at that time no pathway was present in the same area. portant implications regarding land management and protection against future landslides. Recognition of sites previously affected by slope failures, together with the examination of the more likely downslope travel ways of moving material, could greatly help in identifying the most vulnerable areas and in mitigating the effects of future landsliding and flooding events.

\section{The importance of the combined historical-geological approach in the assessment of the landslide hazard}

Mitigation of landslide hazards, and in particular of the hazard related to debris flows, could be accomplished by reducing the interaction between natural processes (erosion, landsliding, sediment transport) and the human systems (Davies, 1997). This requires good knowledge of both landslide source areas, and also the possible areas of invasion by de- bris. Such knowledge should derive from detailed analysis of evidence of past landslide and/or flood events.

The role and potential of historical data to improve the reliability of natural hazard assessment and to mitigate the related risk have long been recognised (Glade et al., 2001). This kind of research is particularly well developed in those areas, such as the European Alps or Japan, where mountain regions have been inhabited since far historical times. The importance of historically-based experience of slope movement occurrence is exemplified by the work of Eisbacher and Clague (1984). There, detailed analysis of the hazard related to destructive mass movements in the Alps of Europe (listing 137 landslide case histories, covering a time span from 328 A.D. to 1976) provided useful information for planning in formerly remote mountainous areas of western Canada, which have been opened to development in the last decades.

In Italy, there is a strong tradition in the use of historiographic data from various sources by Earth scientists. The 

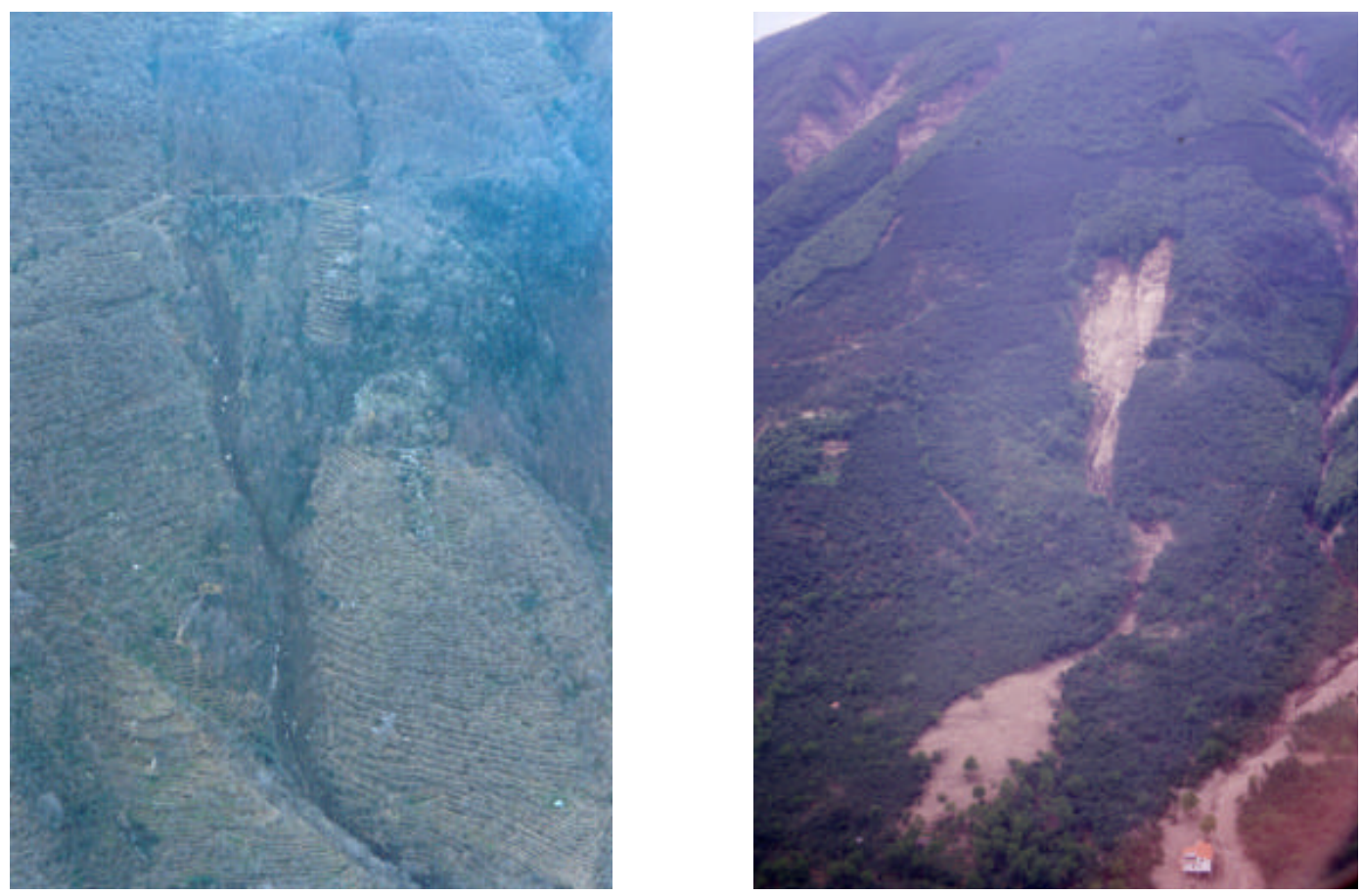

Fig. 10. Comparison from 1997 to 1998 of the main landslides in Lagno Cisierno: the photo at left was taken by A. Santo (University of Naples) on 24 January 1997, few days after the 1997 event; photo at right was taken in June 1998, about one month after the May tragic event. Note the different extent of the area affected by landsliding, and in particular the enlargement of the main landslide area toward the west (to the right in the photos).

remarkable and moving account left by Pliny the Younger about the A.D. 79 eruption of Mount Vesuvius which buried the towns of Pompeii, Herculaneum and Oplonti (Pliny the Younger, unknown date), played an important role in the assessment of the hazard related to explosive eruption from Mt. Vesuvius and similar volcanoes (Sigurdsson et al., 1985).

The seminal historical study of slope movements was Almagià's monography on landslides in Italy (Almagià, 1910). After that work, not until the 1990 AVI project, was Italy provided with a comprehensive nationwide data-bank on landslides, useful especially for reconnaissance-level research. However, knowledge of landslides at a regional and still more local scale is limited. To date, landslide atlases cover very few Italian regions, and those constructed are generally limited to events affecting urban areas (e.g. Annovi and Simoni, 1993; Luino et al., 1993). Furthermore, studies on a single type of slope instability over a certain territory are very rare.

This paper contributes to the body of work dealing with events related to a specific type of slope instability which has occurred repeatedly within a small region. Our three-year study provides information on 45 landsliding and/or flooding events between 1632 and 1998 (Figs. 11 and 12; Table 1). A significant number of events are included within the early part of this period (Fig. 12), although continuity in reports and accounts of early events was not assured. Many of these focus on natural events which predisposed the slopes to future failures (volcanic eruptions), or descriptions of the damage produced by landslides and floods, and consequent claims by citizens for reimbursement by local and regional authorities. However, after World War II, there was good continuity in the availability of information, which came from different sources (municipalities, newspapers, books, etc.). The number of events during this period further testifies to the recurrent threat to towns and infrastructures at the foothills of mountains where loose volcaniclastics overlie carbonate bedrock; a very common situation for large parts of Campania. The overall recurrence interval in the whole study period for debris flows and floods in the study area is about 8 years. In the last three decades, the frequency of events increased to less than 3 years. Considering only the catastrophic events (which determined casualties along with major damages), a return period of about 45 years can be calculated.

The reliability of the available information was evaluated by means of a qualitative three-level ranking (Table 3), following Calcaterra and Parise (2001). Four types of information were looked for in the examined sources, which were considered important for a correct evaluation of the landslide hazard: date of the event, location of the event, slope movement typology, and damage caused by landsliding and/or flooding. Triggering factors were not included in Table 3, since they were rarely reported in the sources. When they were mentioned, rainfall was clearly the trigger for the observed floods or landslides. No documentation was found which directly related the occurrence of landslides to anthropogenic works on the slopes or to seismic events. 
Table 3. Critical evaluation of examined sources. The stars refer to degrees of reliability of the information reported in each group of sources (* = low; $* *=$ medium; $* * *=$ high). Rankings assigned to "Catalogues" and to "Newspapers" sources coincide because the information shown in the "Catalogues" entry are derived entirely from newspapers clippings

\begin{tabular}{lccccc}
\hline Sources & \multicolumn{3}{c}{ Information provided } & Overall validity \\
\hline & date & location & slope movement type & damage & \\
\hline Catalogues & $*$ & $*$ & $*$ & $*$ & low \\
Scientific publications & $*$ & $*$ & $*$ & $*$ & moderate \\
Public Administrations and local & & & & & \\
Management Agencies & $* *$ & $*$ & $*$ & $* *$ & moderate \\
Historiographic studies & $*$ & $*$ & $*$ & $* *$ & moderate \\
Newspapers & $*$ & $*$ & $*$ & $*$ & low \\
Others & $*$ & $*$ & $*$ & $*$ & low \\
\hline
\end{tabular}

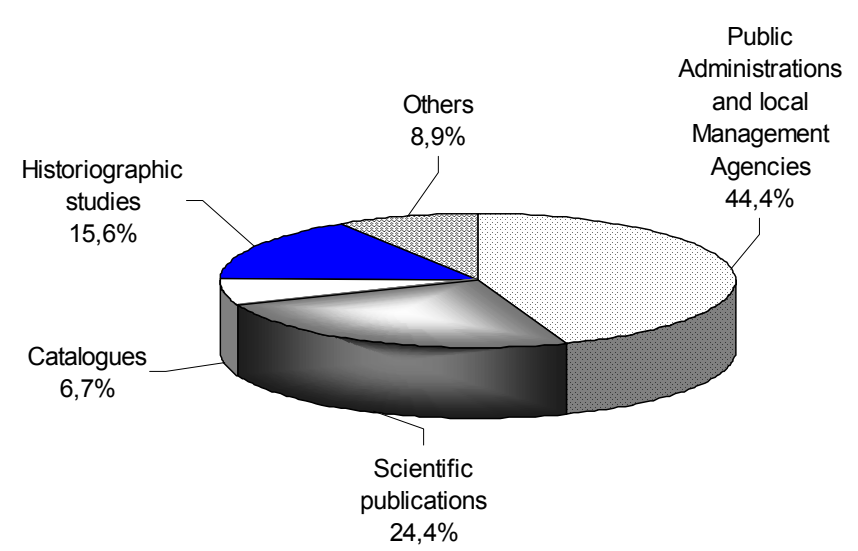

Fig. 11. Categories of sources used in this study, and distribution of identified landslide and flood events. "Historiographic studies" include prevailing books about religious subjects. Information shown in the "Catalogues" entry are derived entirely from newspapers clippings.

As evident from Table 3, no appreciable difference was found between the various sources regarding the quality of information dealing with location and type of slope movement. It was practically impossible to correctly discriminate between debris flows and floods, with some notable exceptions in more recent times, aided by the availability of photographs. Location data are rather vague, but information on sites invaded by landslide or flood deposits are generally more precise than those indicating location of the source areas. This obviously reduces the utility of such information, since uncertainty in the identification of landslide source areas can seriously affect any effort in mitigating the consequent effects. Temporal information are generally approximate, being usually limited to year and month, and only a few cases include the day of the event. Information becomes more complete and reliable after World War II in official documents archived by Public Administrations, especially at a local scale. Throughout the entire period examined, damage to the population and man-made structures is well described only in the case of catastrophic events.
Considering all of the above described types of information, the different sources have been evaluated regarding the overall reliability of reported information (last column in Table 3). As a whole, the examined sources are characterized by a low to moderate reliability, since quality of information, in terms of detail, clarity and completeness, was satisfactory in only a very few cases.

This highlights the main problem encountered in this work, that is the challenge of correctly evaluating the information obtained from historical sources about the occurrence of past episodes of landslides and floods, and their proper use for hazard mitigation. Even for areas characterized by a long history of slope instability, historical information must be cross-checked and confirmed by geological investigation. Only the integration of results from an historical research with the more traditional geological, geomorphologic and engineering-geological approach may effectively help in creating a greater knowledge on both the spatial and temporal distribution of landslide and flood events.

Similar difficulties in the extraction of historical information have been encountered by previous workers. Wieczorek and Jäger (1996), for example, described the historical reports that they used for the inventory of slope movements in the Yosemite Valley of California as frequently fragmentary or inconsistent, which consequently resulted in the underestimation of the actual number of events. In this study, the problem was further complicated by the complexity of Italian history. There have been numerous changes in the political map of Italy over many centuries, and resulting modifications in institutional structures. The influence of these changes on historical data has been pointed out by Guidoboni (2000) in her study of strong earthquakes in Italy. This necessitates a non-superficial analysis of the historical context to better interpret any document or testimony of the damage suffered by the anthropogenic environment from landslides and floods. Our future research will, therefore, include a thorough analysis of all of the information so far collected within the historical and social context of the time. Such work illustrates the potential of cross-disciplinary collaboration between Earth scientists and experts in the interpretation of historical data. 


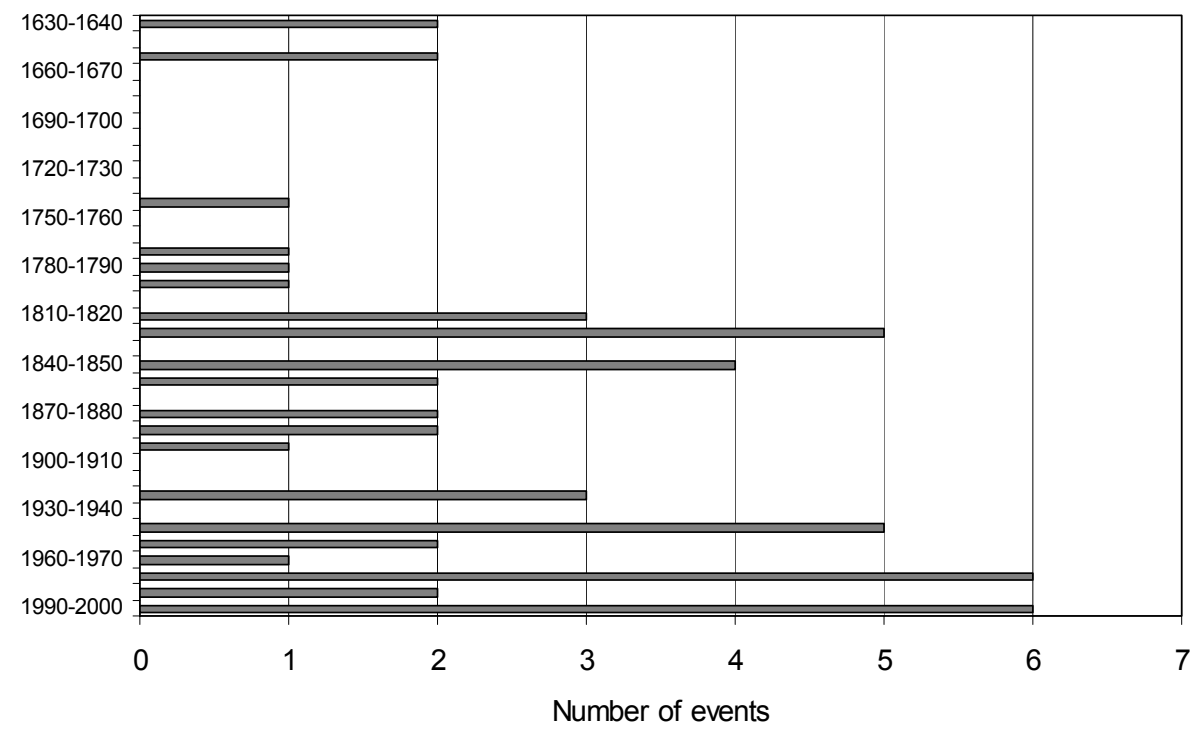

Fig. 12. Temporal distribution of landslide and flood events in the territory of Quindici and the Lauro Valley.
Acknowledgements. We express our warm gratitude to the following people: L. Pelella collaborated with us during most of the field work; A. Santo (University of Naples) provided the photographic documentation regarding the 1997 landslides at Quindici; don Domenico Amelia, parish priest of Quindici, helped us in the research with his valuable publications and his deep knowledge of the history and territory of Lauro Valley. A. Carrara (CNR-CSITE, Bologna) and an anonymous reviewer provided useful comments and suggestions in reviewing the first version of the manuscript. Special thanks are due to F. Whitaker (University of Bristol) whose accurate linguistic revision greatly improved the manuscript. The work was partly supported by Federico II University of Naples (funds granted to D. Calcaterra) and CNR-CERIST, Bari.

\section{References}

Aliberti, G.: Siano in Principato, Eidos Longobardi Ed., Castellammare di Stabia (NA), 184, 1999.

Almagià, R.: Studi geografici sulle frane in Italia, vol. 2, Mem. Soc. Geogr. It., 14, 2, 1910.

Amelia, D.: S. Antonio Abate e la sua chiesa, Tipografia Stefanelli, Nola-Cimitile (NA), 56, 1981.

Amelia, D.: La chiesa dell'Immacolata e le chiese scomparse di Quindici, Scuola Tipo-litografica "Istituto Anselmi”, Marigliano (NA), 336, 1990.

Annovi, A. and Simoni, G. (Eds): Atlante dei centri abitati instabili dell'Emilia-Romagna, CNR-GNDCI/Regione Emilia-Romagna, 1993.

Aversano, V.: La montagna "rimossa" e il piano allagato. In Montagna assassina o vittima?, (Eds) Aversano, V., and Ruggiero, G., Laveglia Editore, 15-60, 2000.

Aversano, V. and Ruggiero, G., (Eds): Montagna assassina o vittima?, Laveglia Editore, 330, 2000.

Barberi, F., Macedonio, G., Pareschi, M. T., and Santacroce, R.: Mapping the tephra fallout risk: an example from Vesuvius (Italy), Nature, 344, 142-144, 1990.

Blair, T. C. and Mc Pherson, J. G.: Alluvial fans and their natural distinction from rivers based on morphology, hydraulic pro- cesses, sedimentary processes, and facies assemblages, J. Sed. Res., A64, 3, 450-489, 1994.

Bonavita, C.: Raccolta di varie notizie attinenti ai Comuni e all'intero circondario di Lauro, 1837.

Boschi, E., Guidoboni, E., Ferrari, G., Mariotti, D., Valensise, G., and Gasperini, P., (Eds): Catalogue of strong Italian earthquakes from 461 B.C. to 1997, Annali di Geofisica, 43, 4, 609-868, with CD-ROM, 2000.

Brancaccio, L., Cinque, A., Russo, F., and Sgambati, D.: Osservazioni geomorfologiche sulle frane del 5-6 maggio 1998 del Pizzo d'Alvano (Monti di Sarno, Campania), In Studi geografici e geologici in onore di Severino Belloni, (Ed) Orombelli, G., Univ. Studi di Milano, 81-123, 1999.

Calcaterra, D. and Parise, M.: The contribution of historical information in the assessment of the landslide hazard, in The use of historical data in natural hazards assessment, (Eds) Glade, T., Albini, P., and Frances, F., Kluwer Academic Publishers, 201-217, 2001.

Calcaterra, D., Parise, M., Palma, B., and Pelella, L.: The 5 May 1998, landsliding event in Campania (southern Italy): inventory of slope movements in the Quindici area, Proc. Int. Symp. on Slope Stability Engineering, Matsuyama, 2, 1361-1366, 1999.

Calcaterra, D., Parise, M., Palma, B., and Pelella, L.: Multiple debris-flows in volcaniclastic materials mantling carbonate slopes, Proc. 2nd Int. Conf. on Debris-Flow Hazards Mitigation, Taipei, 99-107, 2000.

Catenacci, V.: Il dissesto idrogeologico e geoambientale in Italia dal dopoguerra al 1990, Mem. Descr. Carta Geol. d'Italia, 47, 1992.

Costa, J. E. and Jarrett, R. D.: Debris flows in small mountain stream channels of Colorado and their hydrologic implications, Bull. Ass. Eng. Geologists, 18, 309-322, 1981.

Davies, T. R. H.: Using hydroscience and hydrotechnical engineering to reduce debris flow hazards, Proc. 1st Int. Conf. on DebrisFlow Hazards Mitigation, San Francisco, 787-810, 1997.

Del Prete, M., Guadagno, F. M., and Hawkins, A. B.: Preliminary report on the landslides of 5 May 1998, Campania, southern Italy, Bull. Eng. Geol. Env., 57, 113-129, 1998.

Di Maio, G. and Scala, C.: La franosità storica dei rilievi del Pizzo di Vico Alvano. In: Montagna assassina o vittima?, (Eds) Aver- 
sano, V., and Ruggiero, G., Laveglia Editore, 61-88, 2000.

Di Vito, M., Sulpizio, R., and Zanchetta, G.: I depositi ghiaiosi della valle dei Torrenti Clanio e Acqualonga (Campania centroorientale): significato stratigrafico e ricostruzione paleoambientale, Il Quaternario, 11, 2, 1-14, 1998.

Eisbacher, G. H. and Clague, J. J.: Destructive mass movements in high mountains: hazard and management, Geol. Surv. Canada, paper 84-16, 230, 1984

Glade, T., Albini, P., and Frances, F., (Eds): The use of historical data in natural hazards assessment, Kluwer Academic Publishers, 220, 2001.

Guidoboni, E.: Method of investigation, typology and taxonomy of the basic data: navigating between seismic effects and historical contexts, Annali di Geofisica, 43, 4, 621-666, 2000.

Guzzetti, F., Cardinali, M., and Reichenbach, P.: The AVI Project: a bibliographical and archive inventory of landslides and floods in Italy, Environ. Management, 18, 4, 623-633, 1994.

Hatheway, A. W. and Leighton, F. B.: Trenching as an exploratory method, Geol. Soc. America, Reviews in Eng. Geol., 4, 169-195, 1979.

Jackson, L. E. Jr., Kostaschuk, R. A., and Mac Donald, G. M.: Identification of debris flow hazard on alluvial fans in the Canadian Rocky Mountains, in: Debris flows/avalanches: process, recognition, and mitigation, (Eds) Costa, J. E. and Wieczorek, G. F., Geol. Soc. Am. Reviews in Eng. Geology, 7, 115-124, 1987.

Larsen, V. and Steel, R. J.: The sedimentary history of a debris-flow dominated alluvial fan. A study of textural inversion, Sedimentology, 25, 37-59, 1978.

Lazzari, A.: Aspetti geologici dei fenomeni verificatisi nel salernitano in conseguenza del nubifragio del 25-26 ottobre 1954, Boll. Soc. Natur. Napoli, 63, 131-142, 1954.

Luino, F., Ramasco, M., and Susella, G.: Atlante dei centri abitati instabili piemontesi. CNR-GNDCI/Regione Piemonte, 245, 1993.

Migale, L. S. and Milone, A.: Colate di fango in terreni piroclastici della Campania. Primi dati della ricerca storica, Rassegna Storica Salernitana, 30, 15, 2, 235-271, 1998.

Ministero dei Lavori Pubblici, I movimenti franosi in Italia, Consiglio Superiore dei Lavori Pubblici, Roma, 1965.

Parise, M. and Wasowski, J.: Landslide activity maps for landslide hazard evaluation: three case studies from Southern Italy, Natural Hazards, 20, 159-183, 1999.

Penta, F., Lupino, R., Capozza, F. and Esu, F.: Effetti dell'alluvione del 26 ottobre 1954 nel salernitano, Geotecnica, 6, 3-16, 1954.

Pliny the Younger, Epistola a Tacito, VI, 16, 12, unknown date.

Rolandi, G., Barrella, A. M., and Borrelli, A.: The 1631 eruption of Vesuvius. J. Volcanol. Geotherm. Res., 58, 183-201, 1993a.

Rolandi, G., Maraffi, S., Petrosino, P., and Lirer, L.: The Ottaviano eruption of Somma-Vesuvio (8000 y B.P.): a magmatic alternating fall and flow-forming eruption, J. Volcanol. Geotherm. Res., 58, 43-65, $1993 b$.

Rolandi, G., Mastrolorenzo, G., Barrella, A. M., and Borrelli, A.: The Avellino plinian eruption of Somma-Vesuvius (3760 y.B.P.): the progressive evolution from magmatic to hydromagmatic style, J. Volcanol. Geotherm. Res., 58, 67-88, 1993c.

Rosi, M., Principe, C., and Vecci R.: The 1631 Vesuvius eruption. A reconstruction based on historical and stratigraphical data, J. Volcanol. Geotherm. Res., 58, 151-182, 1993.

Scandone, F.: Documenti per la storia dei Comuni dell'Irpinia, vol. 3, Napoli, 1983.

Scandone, R., Bellucci, F., Lirer, L., and Rolandi, G.: The structure of the Campanian Plain and the activity of the Neapolitan volcanoes (Italy), J. Volcanol. Geotherm. Res., 48, 1-31, 1991.

Schuster, R. L.: Socioeconomic significance of landslides, in: Landslides. Investigation and Mitigation, (Eds) Turner, A. K. and Schuster, R. L., Transp. Res. Board, Spec. Rep. 247, Washington, D.C., 12-35, 1996.

Sigurdsson, H., Carey, S., Cornell, W., and Pescatore, T.: The eruption of Vesuvius in A.D. 79, National Geographic Res., 1, 3, 332 387, 1985.

Soeters, S. and van Westen, C. J.: Slope instability recognition, analysis, and zonation, in: Landslides. Investigation and Mitigation, (Eds) Turner, A. K., and Schuster, R. L., Transp. Res. Board, spec. rep. 247, Washington, D.C., 129-177, 1996.

Wieczorek, G. F.: Preparing a detailed landslide-inventory map for hazard evaluation and reduction, Ass. Eng. Geologists Bull., 21, 3, 337-342, 1984

Wieczorek, G. F. and Jäger, S.: Triggering mechanisms and depositional rates of postglacial slope-movement processes in the Yosemite Valley, California, Geomorphology, 15, 17-31, 1996. 